\title{
THE INTERPRETATION OF VERSES 39 OF AN-NUR IN THE PERSPECTIVE OF TAFSIR AND SCIENCE
}

\author{
Afrizal Nur \\ State Islamic University (UIN) Suska Riau \\ Afrizalnur12345@yahoo.com \\ Muhamad Yasir \\ Riau University
}

\begin{abstract}
The dynamics of Qur'an interpretation will always occur and follow the development of the era and time. Every period and interpretation era of the Qur'an will always experience innovation and dynamics both from the methodological, systemic and pattern aspects, presentation, styles of uniqueness of the Mufassir. In this paper the author is interested to examine the interpretation of verse 39 of Surah An-Nur and find the correlation between infidelity which is likened by verse with mirage in the perspective of Tafsir and Science. All forms of good deeds done by unbelievers are likened with mirages. The parables are about the condition of thing with something else, either by using the isti'arah sentence or amsalul Qur'an.
\end{abstract}

Keywords: interpretation, science, mirage.

\section{Introduction}

The Qur'an conveys its messages to human using various ways. The purpose is to make the guidance can be easily accepted by the human. One of the uniqueness of the Qur'an is that the messages delivered in simple, easy, and clear way. And one of the methods is through the expression of comparable.

Amtsal is one of the styles of Qur'an language in conveying its messages that inspires human to use their mind clearly and precisely. Based on this, many scholars tried to focus on studying the style of language and the editorial of the Qur'an in the form of amtsal andalsotry to find the secret behind the phrase. Amtsal in the Qur'an is an abstract visualization in various sentences by way of analogizing something with similar and equal things, then to be able to understand it properly and correctly requires precise and great thought and must be supported by the mastery of stilitik (science of Balaghah).

The literature value contained in the language of Qur'an in the form of amtsal is one of the miracles of the Qur'an. Therefore, the value of literatureuse of the Qur'an cannot be compatible by anyone and anytime, because the Qur'an is not a human product. (Mahbub Nuryadien)

Al Suyuthiy defines the amtsal as descripting the essence of the messages with real images to give bolder mark to the target, such as likening the unclear with the visible one, the unseen with the existing (Jalaluddin al Suyuthiy, al Itqan fi Ulum al Qur'an, j.ii., (Dar Al Fikr, n.y), page 131. Manna 'al Qaththan says, amtsal is emphasizing the messages in an interesting and solid way so it will leaves deep impact to the target, whether in the form of tashbih or in free sentences (Dar Al Fikr, n.y).

Based on the definitions described above, it can be concluded that the amtsal is making parables about something with some other things by using a metaphorical sentence (isti'arah), by anthropomorphism (tashbih) or by other ways. Thus, if it is observed carefully, the parables in the Qur'an use variety of forms, which can be obtained by lessons and advices and also can be captured and understood by common sense. For 
the item that related to the metaphysics, such as the image of heaven's beauty, the attitude of the unbelievers in facing of the instructions and others.

The word of Allah which become the object in this article is one of the amtsal which is categorized as the amtsal Musharrahah: "And for those who disbelieve, their deeds are like a mirage in a flat land, presumed water by who are thirsty ... "

\section{The Interpretation of verse 39 of An-Nur according to Mufassir and Science}

The Qur'an speaks a lot about the phenomena of nature, such as the creation of man, conception of the sky and earth, the rotation of the sun, moon, group of cloud and the rain fall, the phenomenon of flash and lightning, the growth of plants and their species, marine wonders and so on. The verses which speak about natural phenomena are often closed with the suggestion of thinking, reflection and doing other activities of reasoning. It indicates that the Qur'an does not mean to set the principles of this science or explain the details. It means that the Qur'an gives guidance and direction on what is shows: the greatness of His creation and its usefulness for creature.

Moreover, the thing that we cannot doubt is the Qur'an gives an indication of the natural law and the phenomena of this life with a very deep exposure and with a very convincing interpretation. All of that make it impossible to contradict the achievement of human reason in its various phases. We know that scientific discoveries are divided into two parts. The first part is an acceptable discovery of the argument and the reason for approaching the axiom. Meanwhile, the second part is still in the discussion phase (temporary assumptions). All of that exists in the current scientist in the form of hypotheses supported by definite and convincing arguments. But we can see also, every indication that put forward by Qur'an always in accordance with the findings of scientists. (Gamal Al-Bana, 2004: 188)

Muhammad Thahir Ibn 'Assyūr in introduction of his Tafsir formulates the steps of an Ilmi interpretation of which is to bring scientific problems from the theories of science that have to do with the purpose of the Qur'an, then the interpretation that has made should be concise and not included in the interpretation but the conclusion of studying a scientific theory and not adding anything unimportant to the interpretation (Ibn 'Asyur 1:44)

The meaning of the mirage according to Arabic dictionaries. Al Munjid fil lughah: the mirage is an image of waterthat can be seen in middle of the daylight during extremely hot temperature. It was made a parable for a lying and deception (munjid, n.y: 329). Al Qamus al Muhith : the mirage is something you can see it in the middle of daylight, like a water (Abadi, n.y: 124). Lisanul 'Arab; the mirage is something in the middle of the daylight like an image of water flows on flat area. Ibn as Syakit said: the mirage is something is flowing on the earth like water in the middle of the daylight. But the others said:الآل is from dhuha until the sun lapsed, while السراب is from the sun lapsed until ashar prayer time (Lisanul arab, n.y: 462). Tajul 'arus Min Jawahiril Qamus has same meanings. The mirage is something you see it in the middle of the daylight adhere to the earth like water flows (al Husaini, n.y: 52). 


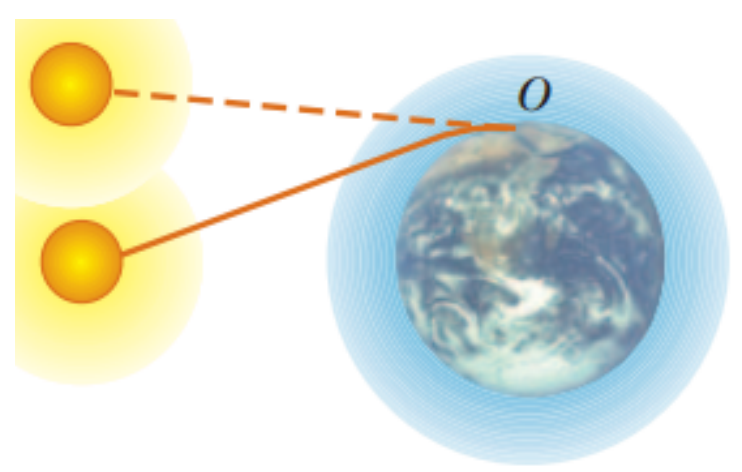

Picture1 :

Modern sciencereveals the developing process of amirageas by: "the shadows formed by refraction in our atmosphere show some interesting phenomena. One of the phenomena that occur in everyday life is the distance of the sun at dusk when passing under the horizon line. The sunlight reaches the Earth's atmosphere (expressed by the shadow region around the planet) and deflectsas it went through in a medium having a different refractive index from previous very empty space. The deflection is somewhat different from previously observed breaks in gradual and continuous conditions, as light travels through the atmosphere to an observer at point $O$. This is because light move through the surface of the air which has regular indexes changing in a continuous way. When the light reaches the observer, the eye follows it backward along the direction from which it appears to come (shown by the dashed path in the figure). As a result the sun appears above the "even horizon" even after the sun is below (Raymond A.Serway, John W Jewwet: 768) the explanation is that because the light is deflected by the Earth's atmosphere, an observer at point $\mathrm{O}$ sees the sun even though it is below the horizon line.

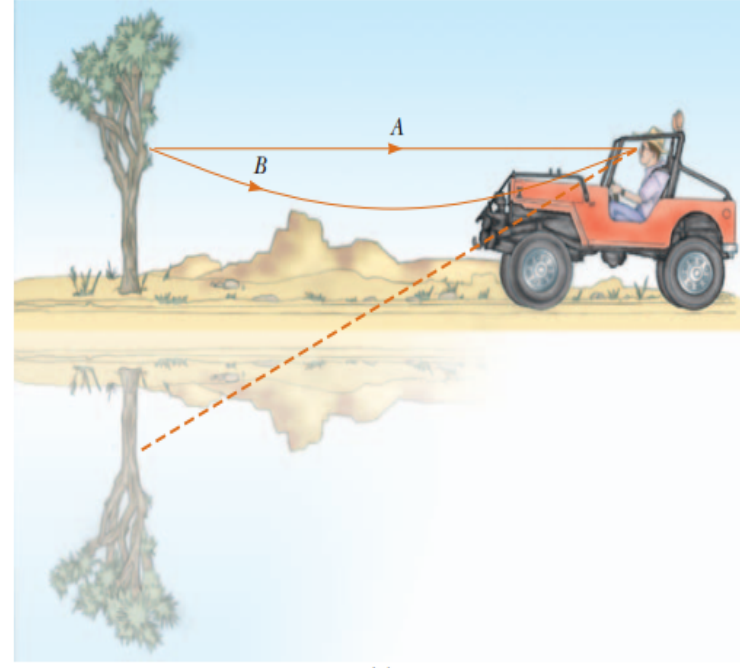

(a)

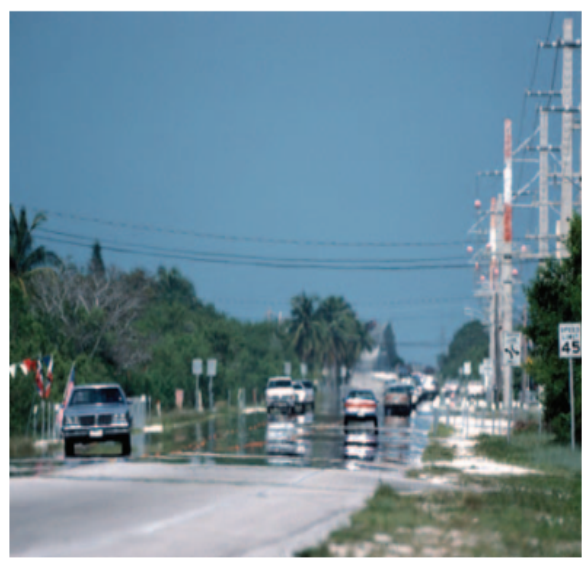

(b)

Picture 2

In this picture the author can explain the mirage is produced by the deflection of the air in the atmosphere because of large difference in temperature between earth and air. (b) Look at the reflection of the car in this mirage image. The streets look flooded with water, but are actually dry.

Mirage is a natural phenomenon produced by refraction in the atmosphere. Mirage can be observed when the earth gets hot then the rising air becomes warmer from the air at the highest elevation. Mirage can occur in the desert with a flat surface area, but a mirage is also present on a warm highway during the summer. Air surfaces at different 
heights above the earth have different densities and different refractive indices. This effect is illustrated in Figure 23.20a. An observer can see the sky and trees in two different ways. With one group of light reaching the observer with a straight-line A, and the eye traces this ray backward to see the tree in a different fashion. Next, the second group of rays rattles along the curved path B. This ray is directly to the ground and then turns as a result of refraction. As a consequence, the observer also sees the inverted image of the tree and the sky background as it traces the rays back to the center point. Because the upright and inverted images appear when the observed tree object in the puddle turns, the observer unconsciously sprouts his experience and concludes that the sky is reflected by a puddle in front of a tree.

Mirage occurs because of the difference in temperature density between cold air temperatures and the temperature of existing hot air coated in the earth's atmosphere. Cold air temperatures have a denser density and are heavier than hot air temperatures that have lower density and are lighter. Therefore, the air layer with the hot air temperature will be close to the soil layer and trapped by a layer of air that is cooler above it, so that the light will refract toward the horizontal line at sight and walk upwards due to the total internal influence. Total internal reflection is a reflection process of light occurring on the boundary surface between one medium and another, having a smaller refractive index, if the second angle of the second node exceeds a certain critical angle. And the light present in the medium with a high refractive index will travel to the lower medium. (Raymond A.Serway: 769) Snell's Law

The following author points out the theory of mirage, The Refraction of Light:

Hugens's principle help us understand why light ray change direction as they cross the boundary between the two media, a phenomenon known as refraction. Refraction is the changing of direction of a light ray as it passes from one medium into another.Use Huygens's principle to understand how refraction occurs. Figure 1.a show a plane wave incident on a planar boundary between air and glass. In the air, a series of planar wavefronts moves toward the glass. The distance between the wavefronts is equal to one wavelength. Once the wavefront reaches the glass boundary and enters the new material, the wave slows down - light move more slowly through glass than through air. Since the wavefront approaches the boundary at an angle to the normal, the portion of the wavefront that is still in air continues at the same merry pace while the part that has entered the glass move more slowly. Figure 1.b shows a Huygens's construction for a wavefront that is partly in glass. The wave has smaller radii in glass since the speed of light is smaller in glass than in air.

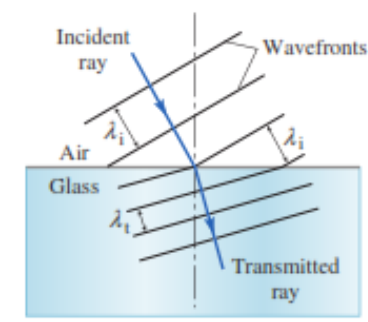

(a)

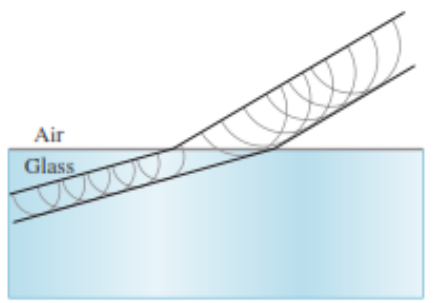

(b)

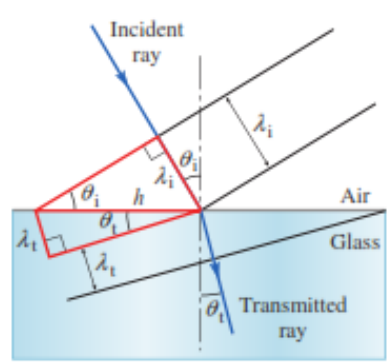

(c)

Figure 1 (a) Wavefronts and rays at a glass-air boundary. The reflected wavefronts are omitted. Note that the wavefronts are closer together in glass because the wavelength is smaller. (b) Huygens's construction for a wavefront partly in air and partly in glass. (c) Geometry for finding the angle of the transmitted ray. 
Figure 1.c show the two right triangles that are used to relate the angle of incidence $\theta_{i}$ to the angle of the transmitted ray (or angle of refraction) $\theta_{t}$. The two triangles share the same hypotenuse $(\mathrm{h})$. using some trigonometry, we find that

Eliminating $\mathrm{h}$ yields

$$
\sin \theta_{i}=\frac{\lambda_{i}}{h} \quad \text { and } \quad \sin \theta_{t}=\frac{\lambda_{t}}{h}
$$

$$
\frac{\sin \theta_{i}}{\sin \theta_{t}}=\frac{\lambda_{i}}{\lambda_{t}}
$$

It is more convenient to rewrite this relationship in terms o the incices of refraction. Recall that when light passes from one transparent medium to another, the frequency $f$ does not change. Since $v=f \lambda$. $\lambda$ is directly proportional to $v$. By definition $[n=c / v$ ], the index of refraction $n$ is inversely proportional to $v$. Therefore, $\lambda$ is inversely proportional to $n$ :

$$
\frac{\lambda_{i}}{\lambda_{t}}=\frac{v_{i} / f}{v_{t} / f}=\frac{v_{i}}{v_{t}}=\frac{c / n_{i}}{c / n_{t}}=\frac{n_{t}}{n_{i}}
$$

By replacing $\lambda_{i} / \lambda_{t}$ with $n_{i} / n_{t}$ in Eq. (1.1) and cross multiplying, we obtain

Snell's Law

$$
n_{i} \sin \theta_{i}=n_{t} \sin \theta_{t}
$$

This law of refraction was discovered experimentally by Dutch professor Willebrord Snell (1580-1626). To determine the direction of the transmitted ray uniquely, two additional statements are needed:

Laws of Refraction

1. $n_{i} \sin \theta_{i}=n_{t} \sin \theta_{t}$, where the angles are measured from the normal.

2. The incident ray, the transmitted ray, and the normal all lie in the same plane (plane of incidence).

3. The incident and transmitted ray are on opposite sides of the normal.

Mathematically, Snell's law treats the two media as interchangeable, so the pats of a light ray transmitted from one medium to another is correct if the direction of the ray is reversed.The index of refraction of material depends on the temperature of the material and on the frequency of the light. In many circumstance the slight variation of $n$ over the visible range of wavelengths can be ignored.

The author provides some views and interpretations of the unbelievers and mirages contained in Surah An-Nur verse 39 as follows:

"And those who disbelieve their deeds are like a mirage on a flat ground, which is presumed water by those who are thirsty, but when he comes to the water he finds nothing. And he finds (Allah) on his side, then Allah gives him the calculation of the deeds with sufficient and Allah is very fast his calculation"

This is the parable that God mentioned for two types of disbeliever. The first is a disbeliever who invites others to follow his infidelity, he feels above the righteous deeds and beliefs, but in truth they are not above the truth. Their parable is like a mirage on a flat land seen from afar as a vast ocean. The word "Qi'atun" is the plural of "Qaa'un, which means a wide flat plain and spread out, usually seen as a mirage. Mirage is usually seen in the middle of the day. When one needs water to see this mirage, surely he thinks it 
is water. Then, they come to him in the hope of drinking from him. When he arrived at that place, it turns out he did not find anything. So is a Gentile who thinks he has done good deeds. He thinks he has obtained something, then when Allah avenges him on the Day of Judgment and recalls and holds accountable for his deeds, he finds his deeds found his deed is something that is not accepted at all. Sometimes, it is because of not sincere and sometimes not follows the rules of shari'ah.

Ubay bin Ka'ab, Abdullah bin Abbas, Mujahid, Qatadah and others in asSahihain mentioned that on the Day of Resurrection, Allah will be ask to the Jews: "what were you worshiping first? They replied: "we worshiped 'Uzair son of God." Then it said to them: "You lie, Allah never takes children. Then, what do you want? They said: "Rabbi, we are thirsty, give us a drink". Then it says: "Do not you see? Then transform the fire of Hell into a mirage that exterminates each other. They ran and shouted: This is the parable of the ignorant Murahkab (fools). (IbnKathir, 6:70)

According to al-Razi in his tafsir Mafatih al-Ghaib: something that appears from afar by the eyes during the day in the desert is like water that flows but not water. (AlRazi 11: 347) Based on M.Quraish Shihab: the mirage is what appears in the vast fields that sparkle like water, every time you approach it, it will stay away from you, until you meet a mountain or a high building, what looks like water disappears from view. In Tafsir al-Muntakhab the mirage is described as an optical event caused by the reflection of the light of the sun and the surface of a field that is not much of a plant. The mirages happen when the light reflects little by little away from the surface of the earth during the day, as the temperature rises, which can then be captured by the eyes of the one who looks at it. at that moment the shadow of the sun is visible on the surface of the earth to resemble a giant mirror that extends over it, and the shadow of a clean blue sky is seen there like a lake. the shadow of the trees also looks upside down also to impress the existence of water, from this description we can draw the conclusion that mirage is an illusion (M.Quraish Shihab, 8: 568). This verse according to the scholars, like the deeds of disbelievers are like mirage, they think the mirage is water so they passionately walk towards the mirage. so disbelievers are unaware of God, they think that happiness is besides Him, in addition to Allah that they worship and the deeds they do are the way of happiness, but in reality their estimates are misplaced. (ibid: 569)

Ibn 'Asyur in his Tafsir explains: "This verse is a verse of Tamsil (parable) that made by Allah SWT to describe the state of two infidels. The first parable describes the state of the militant infidels calling others to their disbelief. They suspect that they are on the right path and belief, when in reality they are completely wrong. Their paraphernalia in this matter is like a mirage visible on a wide flat land from a distance, the landscape looking as if it were like a wavy sea. If a mirage is seen by a thirsty person then he will expect it as water, then he will head in that direction with the intent to drink water from him, but after approaching with mirage he does not get anything. So the unbeliever, he suspects that he has done a good deed, and that he must get a reward, but when they turn to Allah on the Day of Renaissance and Allah recites it and question all the deeds of his deeds, it turns out he does not find anything of what has been done before, even in other epistles God likens their deeds like flying dust (Ibn 'Asyur, $9: 498$ )

Buya Hamka also interprets this verse by recounting: They went on their own in search of the truth, amid the deserts and barren deserts, and on a distant journey he saw a puddle of water, clear, so just looking at it was cool to feel the body, let alone drink it. the journey is continued, the water is visible also, but where it has been taken is not found water, but only the sand, the hotter the heat, the more clearly it appears the water, the more thirsty the clearer the water is clearly visible by the mirage imagination. The question arises where would the water be? Of course no, though clearly visible to the eye, 
is very clearly visible to the eye, let alone the eyes of the man who is thirsty, but it will not exist. It's just a hot symptom. He just resembled water from a distance, but in fact he was not there. so that the traveler's legs until the desert is where he met the fact that his hard-earned pursuit is nothing but a fantasy of the shadows, when he has found the reality where he meets the divine truth, which he should not have to exhaust his energy and is useless if from the beginning he was aware of the warning given by his Lord. his disbelief at the beginning of his footsteps, and his rejection of the Divine doctrine, his punishment has been received in cash, perhaps he died on the ground, not drinking water but eating the sand he thought water was, and he might have realized, but it was too late, expensive to pay because only according to conscience, eye deceit and thirsty pressure. (HAMKA 7: 4948)

Allah likened to their deeds like a mirage, the unbelievers will not be rewarded and rewarded for whatever deeds they have done in the world, even though they do after seeing them in front of their eyes a kind of reward and reward from Allah, but in reality it is not reward or reward but mirage only.

According to Wahbah Al-Zuhaili this verse is an expression and illustration tasybihtamsiliy very beautiful and amazing. The state of unbelievers is contrary to the state of the believers. Their deeds which they regard as sincere deeds and useful to Allah it turns out on the Day of Resurrection they find it useless and very disappointing. Mirage is a glimmer seen by people walking in the middle of a vast expanse in the middle of a very hot day, because of the effects of sunlight, then itlook like of running water or stagnant water on the surface of the soil. The unbelievers are likened to the thirsty whosesee the mirage in an equally upset state when they desperately need to reap the rewards and fruit of their deeds. Whatever their charitable forms such as charity, connecting ropes, helping the poor, and charitable projects, when they die it won't be useful to him.

The practice by the unbelievers who do not want to submit to Allah, deny and do not want to believe the Qur'an and Sunnah, then as many as the infidels who invite and call to follow infidelity, which they think that the deeds Pious that they do is beneficial to them and can save them from His punishment, and in the hereafter what they expect and hope it disappears and get the facts contrary to what they expect and previous perceptions, is like a mirage Seen by someone who is thirsty in the middle of the desert or a vast expanse of land. So the image of the unbelievers in the Hereafter, they think their deeds in the world will bring benefits and save them from the punishment of Allah SWT, when they are dragged by Zabaniyah angels to Hell Jahannam and given boiling drink and pus, those are the people who God said:

Say: "Will we tell you about the people who have the most loss of their deeds?"

Those who have wasted their lives while they think that they do their best.

From verse 39 An-Nur we can understand that the Shari'ah of Allah, rules, order and system is the right light that leads to happiness. As for Shari'ah, rules, and laws other than Shari'ah Allah is like a deceptive mirage. While in the realm of civilization, it is possible that unbelievers become motivators, excels in revealing the mysteries of life, creatively creating various findings and means of development and progress of civilization, but on their salvation in the Hereafter, they are just ignorant and ignorant people, their practice is useless because it is not based on the true principle of belief in Allah and God is not willing to accept a practice but from a person who believes in Him with full and total rural so that the intention of his / her rightfulness. (WahbahAzZuhailiy, 9: 544).

ThanthawiJauhari explained in his tafseer that the definition of the mirage is something is seen at the desert when the sun shine brightly and sharply in dzuhur time. Its 
flows surface of the earth like the water flows (Tanthawi, n.y: 52). And FakhruddinArRazisaid there are two words in Arabic language for Mirage السراب , الآل: And he explained in his tafseer books that the definition of both two words are السراب: is something was seen by eyes in the middle day at the deserts like the water is flowing but it is not water. And everyone see it from far place believe it is water is flowing. And الآل is something was seen by eyes in beginning of the daylight, something small is seen more bigger than it(al Razi, n.y: 7).

FakhruddinArRazi said that form of the tasybih here is whatever the unbeliever do the best deeds in his life, he permanently does not get the reward from it although he believe that he will get the reward from it. But, if he did bad deeds, he will get the punishment from it although he believes he will get the reward from Allah in the day of judgement. But he does not get any reward from Allah even he get incredible punishment and he got incredible sadness. His condition is like someone who has incredible thirsty he very need to the water. When he sees the mirage in the dessert he wants it very much and he hope he will be saved if he got it. When he comes to it, he got nothing then he regrets so much (al Razi, n.y: 7).

The second verse talk about the condition of the unbeliever deeds is:

It means :The deeds of those who disbelieved to their gods is as a dust flown by wind in the thunderstorm they do not get anything from what they did, that is the real going astray. (Ibrahim ; 18 )

The parable form in this verse that the wind in the thunderstorm flied the dust and make it separated one and another until there is no any dust again. And the deeds of the unbelievers are like that. Their paganism lost their deeds. There is no any deeds they have again. The scholarship has different opinion about those deeds (al Razi, n.y: 80).

First : the deed mean ; whatever they did like giving alms, obeying the parent, and feed others, and others, all of their good deed lost because of the do not believe to AllahSWT. If they believe to Allah SWT, all of their good deed will be useful for them.

Second; their deed means; whatever they worship in this world such as statue that they believe that is their faith, they only waste their time and make their body tired a whole time, and their deeds lost.

Third; those deeds ; when they see their all of good deeds lost, and the deeds they believe it's good for them it become lost, they will got incredible regret. Because of it Allah said in his verses: the third verse is :ãß Ïèt7ø9\$\#@»n= Ò9\$\# Ï9오 uqèd It means :Say " Will I convey you the more loser deeds ?(103) Their good deeds lost in the world although they believe that they have did good things (104)

They believe that what they did is an obedient but the real one it is an in violation of Allah law. And if it is an obedient but it is not accepted because of their paganism, they only did all of them to hope reward but they only make their self-tired and they do not get anything (al Razi, n.y: 50).

According to Al-Jazairiy: the bright spotlight of the visible sunlight in the middle of the afternoon which he seems to be like water, while al-Qi'a a vast expanse of land, with no trees and plants, this is a parable that the unbelievers hearts do not exist Goodness and infidelity are the causes and obstacles to the entry of goodness. The practice of the unbelievers brings no benefit and influence to him and is likened to a mirage, and this is also the disclosure of reality. The practice of the unbelievers is a form of wickedness and it is all evil, evil, conspiracy and destruction. Surely they will find their true regret. (AlJazairiy, 3: 62)

According to Al-Sa'diy: This verse is the verse of the amtsal: Allah likens the abrogation of the unbelievers' deeds and their futility with term ... those who disbelieve (disbelievers against Allah and his Messengers). 


\section{Conclusion}

Whatever the form of deeds done by the disbelievers in the world then in the hereafter will not get anything from Allah, this condition was compared with mirage, which looks like water but, it is just a trick of the eye, the unbelievers seem to actually do and do good in social society, but actually in God's eyes does not mean anything, because the Faith is a condition of acceptance of pious charity based on many verses including:

Whoever works righteous deeds, both men and women in a state of faith, Then We will indeed give him a good life and we will surely reward them with a better reward from what they have done. (An-Nahl/16:97)

The above verse we can understand the urgency of faith related to the acceptance or rejection of one's worship charity.

\section{References}

Al-Bana, Gamal 2003, Evolusi Tafsir, Qisti Press, Jakarta.

Giambattista, Alan, Betty McCarthy Richardson, Robert C. Richardson, Physics second edition, 2010, published by McGraw-Hill, Americas, New York.

HAMKA, 2007. Tafsir Al-Azhar, Jilid 7, Pustaka Nasional Singapura.

Ibnu 'Asyur, Muhammad al-Thahir, 1984, al-Tahrir wa al-Tanwir, Darel Tunisiyah, Tunis

Ibn Katsir, 1419H, Tafsir al-Qur'an al-' ${ }^{\mathrm{C}}$ Azim, 1389, 1: 7, Beirut, Dar al-Fikri.

al-Jazairi, Abu Bakar. Tafsir Aisar al-Tafaasir, 2002, Arab Saudi, Maktabah al-' Ulum

al-Jauhari, Thantawi. Al-Jawahir, Musthafa al-al-Bab al-Halabi wa Awladuhu, Mesir

Nuryadien, Mahbub. Jurnal al Tarbawi al Haditsah; Metode Amstal : metode Al-Qur'an Membangun Karakter, vol 1 no 1, 2016, ISSN 2407-6805, IAIN Syaikh Nur Jati Cirebon

Al-Qaththan, Manna'. 1973. Mabahits fi Ulum al Qur'an, Beirut : al Syirkah al Mutthahidah li al Tauzi.

Al-Razi, Mafatih al-Ghaib, Maktabah Syamilah, jilid 11

al-Sa ${ }^{\mathrm{c}}$ diy, Abdurrahman bin Naasir al-Din. 2002, Taisir al-Karim al-Rahman fi Tafsir Kalamal-Mannan, Beirut, Libanon, Risalah Publisher

Serway, Raymond A. \& Jewwet, John W.2010. College Physics 7th edition, Thomson Brooks/Cole

Shihab, M. Quraish 2009, Tafsir al-Mishbah Pesan, Kesan dan Keserasian al-Qur'an, Jakarta, Lentera Hati,

al-Zuhaili, Wahbah. 2014. Tafsir Al-Munir Transl. Abdul Hayy Al-Kattani, GIP, Jakarta. 